\title{
Chemical composition of cactus pear cladodes under different fertilization and harvesting managements
}

\author{
Gil Mario Ferreira Gomes ${ }^{(1)}$, Magno José Duarte Cândido(1), Marcos Neves Lopes ${ }^{(1)}$, \\ Theyson Duarte Maranhão(1), Dhones Rodrigues de Andrade(1), Jander Fabrício Martins Costa(1), \\ Walisson Marques Silveira ${ }^{(1)}$ and José Neuman Miranda Neiva(2)
}

\begin{abstract}
(1)Universidade Federal do Ceará, Departamento de Zootecnia, Avenida Mister Hall, no 2.977, Bloco 808, Pici, CEP 60440-554 Fortaleza, CE, Brazil. E-mail: gilmariofg@yahoo.com.br, magno@ufc.br, nevesvv@yahoo.com.br, theysonduarte@gmail.com, dhones-bv@hotmail.com, janderfmc@hotmail.com, walisson_gt@yahoo.com.br (2)Universidade Federal do Tocantins, Escola de Medicina Veterinária e Zootecnia, Rua Humberto Campos, no 508, São João, CEP 77804-060 Araguaína, TO, Brazil. E-mail: araguaia2007@gmail.com
\end{abstract}

\begin{abstract}
The objective of this work was to evaluate the effects of combined phosphorus and nitrogen fertilization and of harvesting frequency on the chemical composition of 'Gigante' cactus pear (Opuntia ficus-indica) cladodes. The experiment was carried out in two municipalities, Quixadá and Tejuçuoca, in the state of Ceará, Brazil. Fertilization with nitrogen (urea) and phosphorus (single superphosphate) was done with nine doses, respectively: 10 and 70,70 and 10, 70 and 70, 70 and 130, 100 and 100,130 and 70,130 and 130, 130 and 190, and 190 and $130 \mathrm{~kg} \mathrm{ha}^{-1}$ per year, besides $100 \mathrm{~kg} \mathrm{ha}^{-1} \mathrm{~N}$ and $\mathrm{P}_{2} \mathrm{O}_{5}$ per year as the control. The harvesting frequencies evaluated were annual and biannual. A randomized complete block design was adopted, in split plot, with four replicates. The effect of fertilization on the contents of total dry matter, crude protein, neutral detergent fiber, organic matter, and total carbohydrates in the cladodes varies with harvesting frequency and site. Regarding harvesting frequency, there were higher contents of organic matter, total carbohydrates, and neutral detergent fiber, but lower contents of crude protein for the biannual harvesting in both municipalities. Annual harvesting improves the nutritional quality of primary and secondary cladodes in the municipality of Quixadá and of secondary and tertiary cladodes in Tejuçuoca.
\end{abstract}

Index terms: Opuntia ficus-indica, harvesting frequency, nitrogen, phosphorus.

\section{Composição química de cladódios de palma forrageira sob diferentes manejos de adubação e colheita}

\begin{abstract}
Resumo - O objetivo deste trabalho foi avaliar os efeitos da adubação combinada de nitrogênio e fósforo, e da frequência de colheita sobre a composição química de cladódios de palma forrageira 'Gigante' (Opuntia ficusindica). O experimento foi realizado em dois municípios cearenses, Quixadá e Tejuçuoca. A adubação com nitrogênio (ureia) e fósforo (superfosfato simples) foi realizada em nove doses, respectivamente: 10 e 70, 70 e 10, 70 e 70, 70 e 130, 100 e 100, 130 e 70, 130 e 130, 130 e 190, e 190 e $130 \mathrm{~kg} \mathrm{ha}^{-1}$ por ano, além de $100 \mathrm{~kg}$ $\mathrm{ha}^{-1}$ de $\mathrm{N} \mathrm{e} \mathrm{P}_{2} \mathrm{O}_{5}$ por ano como controle. As frequências de colheita avaliadas foram anual e bianual. Adotou-se o delineamento de blocos ao acaso, em arranjo de parcelas subdivididas, com quatro repetições. $\mathrm{O}$ efeito da adubação sobre os teores de matéria seca total, proteína bruta, fibra em detergente neutro, matéria orgânica e carboidratos totais dos cladódios varia com a frequência de colheita e com o local. Quanto aos períodos de colheita, foram observados maiores teores de matéria orgânica, carboidratos totais e fibra em detergente neutro, mas menores teores de proteína bruta para a colheita bianual, nos dois municípios. A colheita anual melhora a qualidade nutritiva de cladódios primários e secundários em Quixadá e de cladódios secundários e terciários em Tejuçuoca.
\end{abstract}

Termos para indexação: Opuntia ficus-indica, frequência de colheita, nitrogênio, fósforo.

\section{Introduction}

Cactus pear [Opuntia ficus-indica (L.) Mill.] is one of the main foods used for flocks of arid and semiarid regions of the world. The main reason is its ability to remain productive and nutritious in conditions of water deficit (Nobel \& Zutta, 2008). Although cactus pear is high in energy and digestibility, low protein and fiber contents limit its use in the ruminant diet. 
Nitrogen fertilization is used to increase the crude protein content of this species. Dubeux Jr et al. (2006) obtained an increase from 7 to $13 \mathrm{~g} \mathrm{~kg}^{-1}$ dry matter with the addition to the soil of $300 \mathrm{~kg} \mathrm{ha}^{-1} \mathrm{~N}$ for clone-20 of cactus pear. Combined doses of nitrogen and phosphorus may potentiate this effect because the absorbable forms of these nutrients interact synergistically (Prado, 2008). Another factor that could alter the nutritional quality of this species is harvesting frequency; however, little is known about this effect.

The nutritional quality of cactus pear is not homogeneous, since its cladodes (succulent stems without leaves) are at different stages of development in the plant. Young cladodes are located more at the top and are richer in water, ash and crude protein, but poorer in fiber; the opposite is observed for cladodes located at the base of the plant. In addition, younger cladodes act as a growth drain (PimientaBarrios et al., 2005) and, therefore, use sugars for respiration and synthesis of other molecules (Taiz \& Zeiger, 2006), which reduces carbohydrate content (Ribeiro et al., 2010). The evaluation of cactus pear quality considering the order of cladodes is still poorly investigated, mainly regarding the effect of fertilization and the frequency of harvesting. Under appropriate management conditions, young cladodes may have a CP content (190 $\mathrm{g} \mathrm{kg}^{-1}$ dry matter) as high as that produced by leucaena (190 $\mathrm{g} \mathrm{kg}^{-1}$ dry matter) (Pinos-Rodríguez et al., 2010).

The objective of this work was to evaluate the effects of combined phosphorus and nitrogen fertilization and of harvesting frequency on the chemical composition of 'Gigante' cactus pear cladodes.

\section{Materials and Methods}

Two experiments were carried out from January 2011 to March 2013. The first one was developed at the Lavoura Seca farm, in the municipality of Quixada $\left(4^{\circ} 58^{\prime} \mathrm{S}, 39^{\circ} 01^{\prime} \mathrm{W}\right.$, at an altitude of $\left.190 \mathrm{~m}\right)$, and the second one, at the Quilombo farm, in the municipality of Tejuçuoca $\left(3^{\circ} 59^{\prime} \mathrm{S}, 39^{\circ} 34^{\prime} \mathrm{W}\right.$, at an altitude of 140 $\mathrm{m})$, both located in the state of Ceará, Brazil. Data of rainfall, temperature, and average relative humidity obtained in 2011 and 2012 were, respectively, 1,042 and $602 \mathrm{~mm}, 27$ and $26.9^{\circ} \mathrm{C}$, and 61.3 and $56.3 \%$ in Quixadá; and 1,038 and $561 \mathrm{~mm}, 26$ and $26.8^{\circ} \mathrm{C}$, and 67.2 and $63.8 \%$ in Tejuçuoca. Soil chemical properties at $0.00-0.20-\mathrm{m}$ depth were, respectively, for Quixadá and Tejuçuoca: $\mathrm{pH} 6.1$ and $6.2 ; 5$ and $6 \mathrm{mg} \mathrm{dm}^{-3} \mathrm{P}$; 260 and $243 \mathrm{mg} \mathrm{dm}^{-3} \mathrm{~K} ; 20$ and $7 \mathrm{mg} \mathrm{dm}^{-3} \mathrm{Na} ; 3.4$ and $4.0 \mathrm{cmol}_{\mathrm{c}} \mathrm{dm}^{-3} \mathrm{Ca} ; 3.4$ and $3.2 \mathrm{cmol}_{\mathrm{c}} \mathrm{dm}^{-3} \mathrm{Mg}$; absent $\mathrm{Al}$; sum of bases of 7.55 and $7.85 \mathrm{cmol}_{\mathrm{c}} \mathrm{dm}^{-3}$; effective cation exchange capacity of 7.55 and $7.85 \mathrm{cmol}_{\mathrm{c}} \mathrm{dm}^{-3}$; and organic matter of 5.28 and $8.17 \mathrm{~g} \mathrm{~kg}^{-1}$, respectively. The physical characteristics of the soils for Quixadá and Tejuçuoca were, respectively: 513 and $164 \mathrm{~g} \mathrm{~kg}^{-1}$ coarse sand; 363 and $590 \mathrm{~g} \mathrm{~kg}^{-1}$ fine sand; 89 and 153 $\mathrm{g} \mathrm{kg}^{-1}$ silte; 35 and $93 \mathrm{~g} \mathrm{~kg}^{-1}$ clay; 2.62 and $2.57 \mathrm{~g} \mathrm{~kg}^{-1}$ particle density; and sandy and sandy loam textural classification.

A randomized complete block design was adopted, in split plot, with four replicates. The treatments consisted of nine combinations of nitrogen (urea, $45 \% \mathrm{~N}$ ) and phosphorus (single superphosphate, $18 \%$ $\mathrm{P}_{2} \mathrm{O}_{5}$ ), according to matrix Plan Puebla II (Turrent Fernández \& Laird, 1975), assigned to the plots, and two harvesting frequencies (annual and biannual), assigned to the subplots, totaling 72 experimental units, with three rows of cactus pear and 120 plants per plot, in each municipality. The dose $100 \mathrm{~kg} \mathrm{ha}^{-1} \mathrm{~N}$ and $\mathrm{P}_{2} \mathrm{O}_{5}$ per year was considered as a reference (control) between the following combinations: 10 and 70,70 and 10, 70 and 70, 70 and 130, 100 and 100, 130 and 70, 130 and 130, 130 and 190, and 190 and $130 \mathrm{~kg} \mathrm{ha}^{-1} \mathrm{~N}$ and $\mathrm{P}_{2} \mathrm{O}_{5}$ per year, respectively.

Planting was performed before the beginning of the rainy season. Cladodes were buried $30 \mathrm{~cm}$ deep in the furrow in a vertical position, covered $2 / 3$, and kept dried. The spacing was $2.0 \times 0.10 \mathrm{~m}$, totaling 50,000 plants per hectare. Fertilization was applied in the rainy season, in which phosphorus was available at once and urea fractionated in three applications, with intervals of 20 days. Urea was diluted in $1 \mathrm{~L}$ of water to allow the application of the lowest dose of nitrogen and phosphorus. The micronutrient source was FTE-BR 12 $(0.1 \% \mathrm{Mo}, 0.8 \% \mathrm{Cu}, 1.8 \% \mathrm{~B}, 2.0 \% \mathrm{Mn}, 3.0 \% \mathrm{Fe}$, and $9.0 \% \mathrm{Zn}$ ) applied at $50 \mathrm{~kg} \mathrm{ha}^{-1}$ per year, and the balance of $\mathrm{Ca}$ and $\mathrm{S}$ was carried out using agricultural gypsum and limestone, based on the maximum dose of single superphosphate; all were available immediately.

One or two plants of the central row of each experimental plot were taken for collection of cladodes. Samples of cladodes were pre-dried in a forced-air oven at $55^{\circ} \mathrm{C}$ to constant mass and then subjected to the laboratory analysis. Content of dry matter (DM, method

Pesq. agropec. bras., Brasília, v.53, n.2, p.221-228, Feb. 2018

DOI: 10.1590/S0100-204X2018000200011 
ID 930.15) and crude protein (CP, method ID 984.13) were determined according to the procedures described in Helrich (1990). The organic matter content (OM) was calculated by subtracting the ash content (method ID 924.05) from 100. The neutral detergent fiber (NDF) content was determined according to Van Soest \& Robertson (1985). NDF analyses were not treated with amylase and neither corrected for ash and protein. The carbohydrate content was estimated as proposed by Sniffen et al. (1992): total carbohydrates $(\mathrm{TC})=100$ $(\% \mathrm{CP}+\% \mathrm{EE}+\% \mathrm{ash})$, where $\mathrm{EE}$ is the ether extract.

In order to evaluate the effect of fertilization, the chemical composition variables were subjected to the regression analysis, for which the selection of the models was based on the significance of the coefficients up to $10 \%$ probability, by the F-test, and of the coefficient of determination, using the SAEG software, version 9.1 (SAEG..., 2007). As for the effect of the frequency of harvesting, the mean values were compared by Tukey's test, at $5 \%$ probability, in the SAS software (SAS Institute Inc., Cary, NC, USA).

\section{Results and Discussion}

The doses of $\mathrm{N}$ and $\mathrm{P}$ affected the total dry matter content (DMT) of cladodes, except of primary and secondary cladodes under annual harvest, in the municipality of Quixadá (Table 1), and of tertiary cladodes under annual harvesting in Tejuçuoca (Table 2), in which there was no fit for the $\mathrm{N}$ and $\mathrm{P}$ doses. In Tejuçuoca, the DMT content of primary cladodes in the two harvesting frequencies was fit to the multiple regression model. For secondary cladodes, in Tejuçuoca, in the two harvesting frequencies, there was a quadratic effect of the doses of $\mathrm{P}$ on the DMT content, and for tertiary cladodes, under biannual harvesting, there was a quadratic effect of the $\mathrm{N}$ doses on the DMT content. The increase or reduction in the DMT content of cladodes as a function of fertilization is a reflection of the indirect effect of soil nutrients on the growth dynamics of the whole cactus pear plant. Nerd \& Mizrahi (1994) reported that the increase in $\mathrm{N}$ fertilization increased the number of cladodes per

Table 1. Regression equations and coefficients of determination $\left(\mathrm{R}^{2}\right)$ of the contents of: total dry matter (DMT), organic matter (OM), crude protein (CP), total carbohydrates (TC), and neutral detergent fiber (NDF) of primary and secondary cladodes of 'Gigante' cactus pear (Opuntia ficus-indica), under annual and biannual harvesting frequencies, in the municipality of Quixadá, in the state of Ceará, Brazil, according to the combined doses of nitrogen (N, urea) and phosphorus $\left(\mathrm{P}, \mathrm{P}_{2} \mathrm{O}_{5}\right)$ evaluated.

\begin{tabular}{|c|c|c|c|c|}
\hline Cladode order & $\begin{array}{l}\text { Harvesting } \\
\text { frequency }\end{array}$ & $\begin{array}{c}\text { Nutrients } \\
\left(\mathrm{g} \mathrm{kg}^{-1}\right)\end{array}$ & Regression & $\mathrm{R}^{2}$ \\
\hline \multirow{5}{*}{ Primary } & \multirow{5}{*}{ Annual } & DMT & $\mathrm{Y}=136.03$ & $-(1)$ \\
\hline & & $\mathrm{OM}$ & $\mathrm{Y}=917.39$ & - \\
\hline & & $\mathrm{CP}$ & $\mathrm{Y}=53.6719+0.09246 * \mathrm{~N}$ & 0.40 \\
\hline & & $\mathrm{TC}$ & $\mathrm{Y}=816.6580+0.4308 * \mathrm{~N}-0.002330 * \mathrm{~N}^{2}$ & 0.34 \\
\hline & & NDF & $\mathrm{Y}=174.950-0.2054 \mathrm{~N}+0.009142 * * \mathrm{~N}^{2}+2.6457 * * * \mathrm{P}-0.02125^{* * *} \mathrm{NP}$ & 0.99 \\
\hline \multirow{5}{*}{ Primary } & \multirow{5}{*}{ Biannual } & DMT & $\mathrm{Y}=251.2060-1.2231 * \mathrm{P}+0.004461 * \mathrm{P}^{2}$ & 0.71 \\
\hline & & $\mathrm{OM}$ & $\mathrm{Y}=904.3890+0.2490 * \mathrm{~N}-0.001454 * * \mathrm{~N}^{2}+0.3062 * * \mathrm{P}-0.001181 * \mathrm{P}^{2}$ & 0.66 \\
\hline & & $\mathrm{CP}$ & $\mathrm{Y}=34.3130-0.04252 \mathrm{~N}+0.0004518^{\circ} \mathrm{N}^{2}+0.05443^{*} \mathrm{P}$ & 0.71 \\
\hline & & $\mathrm{TC}$ & $\mathrm{Y}=851.9640+0.3082^{*} \mathrm{~N}-0.002060^{* *} \mathrm{~N}^{2}+0.2611^{\circ} \mathrm{P}-0.001292^{\circ} \mathrm{P}^{2}$ & 0.54 \\
\hline & & NDF & $\mathrm{Y}=122.0780+2.8241 * * * \mathrm{~N}+1.4340 * * \mathrm{P}+0.008454 * * \mathrm{P}^{2}-0.02706 * * * \mathrm{NP}$ & 0.57 \\
\hline \multirow{5}{*}{ Secondary } & \multirow{5}{*}{ Annual } & DMT & $\mathrm{Y}=148.33$ & - \\
\hline & & $\mathrm{OM}$ & $\mathrm{Y}=866.3180+0.1224 \mathrm{~N}+0.001123^{\circ} \mathrm{N}^{2}+0.3864^{*} \mathrm{P}-0.002825^{\circ} \mathrm{NP}$ & 0.65 \\
\hline & & $\mathrm{CP}$ & $\mathrm{Y}=78.67$ & - \\
\hline & & $\mathrm{TC}$ & $\mathrm{Y}=746.0740+0.4769^{\circ} \mathrm{N}+0.5937^{\circ} \mathrm{P}-0.004888^{\circ} \mathrm{NP}$ & 0.43 \\
\hline & & NDF & $\mathrm{Y}=284.2490-0.2640 * * \mathrm{~N}$ & 0.42 \\
\hline \multirow{5}{*}{ Secondary } & \multirow{5}{*}{ Biannual } & DMT & $\mathrm{Y}=280.490-1.8693 * * \mathrm{P}+0.007021 * \mathrm{P}^{2}$ & 0.74 \\
\hline & & $\mathrm{OM}$ & $\mathrm{Y}=897.2140+0.1806^{\circ} \mathrm{N}-0.001082^{\circ} \mathrm{N}^{2}+0.3090^{*} \mathrm{P}-0.001072^{\circ} \mathrm{P}^{2}$ & 0.56 \\
\hline & & $\mathrm{CP}$ & $\mathrm{Y}=40.9892+0.05049 * * \mathrm{~N}$ & 0.57 \\
\hline & & $\mathrm{TC}$ & $\mathrm{Y}=848.7450-0.09741^{\circ} \mathrm{N}+0.08606^{\circ} \mathrm{P}$ & 0.30 \\
\hline & & NDF & $\mathrm{Y}=234.4710+1.0189 * * \mathrm{~N}-0.1173 \mathrm{P}+0.004665 * * \mathrm{P}^{2}-0.008056^{*} \mathrm{NP}$ & 0.53 \\
\hline
\end{tabular}

(1)Lack of fit to doses of $\mathrm{N}$ and P. ***, **,*and ${ }^{\circ}$ Significant at $0.1,1,5$, and $10 \%$ probability, respectively. 
plant, resulting in two distinct events, that is, in the increase and reduction of DM content of the basal and apical cladodes, respectively.

Cladodes at the base of the plant started to perform a support function in the municipality of Tejuçuoca, because the increase in $\mathrm{N}$ doses resulted in an increase in the DMT content of primary cladodes and in a reduction in that of tertiary cladodes. The same behavior was not observed in Quixadá, probably due to sandy soil with lower rainwater storage capacity. The higher availability of water in the soil contributes to reduce the DM content of cactus pear (Dubeux Júnior et al., 2010), which may explain the lower DMT content in cladodes evaluated in Tejuçuoca. In this municipality, the DMT content of cladodes was similar to those observed by Santos (2006), mean of $102 \mathrm{~g} \mathrm{~kg}^{-1}$, and Batista et al. (2009), mean of $153 \mathrm{~g} \mathrm{~kg}^{-1}$.

The CP content of primary cladodes under annual harvesting in both municipalities increased linearly with $\mathrm{N}$ doses. Therefore, the dose of $190 \mathrm{~kg} \mathrm{ha}^{-1} \mathrm{~N}$ per year in Quixadá (Table 1), and the combined dose of 190 and $10 \mathrm{~kg} \mathrm{ha}^{-1}$ per year $\mathrm{N}$ and $\mathrm{P}_{2} \mathrm{O}_{5}$ in Tejuçuoca (Table 2), provided maximum $\mathrm{CP}$ content, with estimates of 71.2 and $83.2 \mathrm{~g} \mathrm{~kg}^{-1} \mathrm{DM}$, respectively. A similar effect was observed for secondary cladodes with biannual harvesting in Quixadá and with annual

Table 2. Regression equations and coefficients of determination $\left(\mathrm{R}^{2}\right)$ of the content of total dry matter (DMT), organic matter (OM), crude protein (CP), total carbohydrates (TC), and neutral detergent fiber (NDF) of primary, secondary, and tertiary cladodes of 'Gigante' cactus pear (Opuntia ficus-indica), under annual and biannual harvesting frequencies, in the municipality of Tejuçuoca, in the state of Ceará, Brazil, according to the combined doses of nitrogen (N, urea) and phosphorus $\left(\mathrm{P}, \mathrm{P}_{2} \mathrm{O}_{5}\right)$ evaluated.

\begin{tabular}{|c|c|c|c|c|}
\hline Cladode order & $\begin{array}{l}\text { Harvesting } \\
\text { frequency }\end{array}$ & $\begin{array}{c}\text { Nutrients } \\
\left(\mathrm{g} \mathrm{kg}^{-1}\right)\end{array}$ & Regression & $\mathrm{R}^{2}$ \\
\hline & & DMT & $\mathrm{Y}=125.2030-0.01833 \mathrm{~N}-0.001350 * * \mathrm{~N}^{2}-0.3448 * * \mathrm{P}+0.002968 * * \mathrm{NP}$ & 0.71 \\
\hline & & $\mathrm{OM}$ & $\mathrm{Y}=886.1650+0.2077^{\circ} \mathrm{N}-0.0009083^{\circ} \mathrm{N}^{2}$ & 0.41 \\
\hline \multirow[t]{5}{*}{ Primary } & Annual & $\mathrm{CP}$ & $\mathrm{Y}=66.1383+0.09524 * * * \mathrm{~N}-0.1070 \mathrm{P}+0.0006526^{\circ} \mathrm{P}^{2}$ & 0.88 \\
\hline & & $\mathrm{TC}$ & $\mathrm{Y}=805.28$ & $-(1)$ \\
\hline & & $\mathrm{NDF}$ & $\mathrm{Y}=271.410+0.6109 \mathrm{~N}+0.007758^{*} \mathrm{~N}^{2}+0.7926^{\circ} \mathrm{P}+0.006336^{*} \mathrm{P}^{2}-0.01867 * \mathrm{NP}$ & 0.45 \\
\hline & & DMT & $\mathrm{Y}=64.9365+0.5117 * * * \mathrm{~N}+0.4463^{* * *} \mathrm{P}-0.004752 * * * \mathrm{NP}$ & 0.81 \\
\hline & & $\mathrm{OM}$ & $\mathrm{Y}=854.7070+0.4699 * * * \mathrm{~N}-0.001897 * * \mathrm{~N}^{2}+0.4889 * * * \mathrm{P}-0.001799 * * \mathrm{P}^{2}$ & 0.79 \\
\hline \multirow[t]{5}{*}{ Primary } & Biannual & $\mathrm{CP}$ & $\mathrm{Y}=79.6120-0.2182 * \mathrm{~N}-0.2569 * \mathrm{P}+0.003172 * * \mathrm{NP}$ & 0.60 \\
\hline & & $\mathrm{TC}$ & $\mathrm{Y}=753.8710+0.7334 * * * \mathrm{~N}+0.8139 * * * \mathrm{P}-0.007465 * * * \mathrm{NP}$ & 0.63 \\
\hline & & $\mathrm{NDF}$ & $\mathrm{Y}=231.6760+2.5386 * * * \mathrm{~N}+1.8449 * * * \mathrm{P}-0.01794 * * * \mathrm{NP}$ & 0.97 \\
\hline & & DMT & $\mathrm{Y}=105.2160-0.2114 * \mathrm{P}+0.0007922 * \mathrm{P}^{2}$ & 0.57 \\
\hline & & $\mathrm{OM}$ & $\mathrm{Y}=904.0660-0.2736 * \mathrm{P}+0.001134 * \mathrm{P}^{2}$ & 0.64 \\
\hline \multirow[t]{5}{*}{ Secondary } & Annual & $\mathrm{CP}$ & $\mathrm{Y}=73.3145+0.1177^{* * *} \mathrm{~N}$ & 0.80 \\
\hline & & $\mathrm{TC}$ & $\mathrm{Y}=796.1710-0.1417 * * \mathrm{P}$ & 0.58 \\
\hline & & $\mathrm{NDF}$ & $\mathrm{Y}=60.3589+1.8923 * * * \mathrm{~N}+0.003933 * * \mathrm{~N}^{2}+2.5317 * * * \mathrm{P}-0.02338 * * * \mathrm{NP}$ & 0.83 \\
\hline & & DMT & $\mathrm{Y}=91.7004+0.1536 \mathrm{P}-0.0009195^{\circ} \mathrm{P}^{2}$ & 0.28 \\
\hline & & $\mathrm{OM}$ & $\mathrm{Y}=856.1890+0.5554^{* * *} \mathrm{~N}-0.002296^{* *} \mathrm{~N}^{2}+0.2763^{*} \mathrm{P}-0.001004^{\circ} \mathrm{P}^{2}$ & 0.73 \\
\hline \multirow[t]{5}{*}{ Secondary } & Biannual & $\mathrm{CP}$ & $\mathrm{Y}=80.1902-0.1788^{\circ} \mathrm{N}-0.2111 * \mathrm{P}+0.002757^{* *} \mathrm{NP}$ & 0.63 \\
\hline & & $\mathrm{TC}$ & $\mathrm{Y}=757.9670+0.5555 * \mathrm{~N}-0.002625 * \mathrm{~N}^{2}+0.6544 * * \mathrm{P}-0.003237 * \mathrm{P}^{2}$ & 0.52 \\
\hline & & $\mathrm{NDF}$ & $\mathrm{Y}=302.5950+2.4640 * * * \mathrm{P}-0.0101 * * * \mathrm{P}^{2}$ & 0.46 \\
\hline & & DMT & $\mathrm{Y}=84.75$ & - \\
\hline & & $\mathrm{OM}$ & $\mathrm{Y}=862.5990+0.4060^{*} \mathrm{~N}-0.1621 \mathrm{P}+0.002085^{*} \mathrm{P}^{2}-0.003453^{\circ} \mathrm{NP}$ & 0.58 \\
\hline \multirow[t]{5}{*}{ Tertiary } & Annual & $\mathrm{CP}$ & $\mathrm{Y}=63.4663+0.6601^{* *} \mathrm{~N}-0.002529^{* *} \mathrm{~N}^{2}+0.3254^{\circ} \mathrm{P}-0.001420^{\circ} \mathrm{P}^{2}$ & 0.91 \\
\hline & & $\mathrm{TC}$ & $\mathrm{Y}=755.0910-0.1818 * \mathrm{~N}$ & 0.32 \\
\hline & & $\mathrm{NDF}$ & $\mathrm{Y}=232.580+0.2970 * \mathrm{~N}$ & 0.40 \\
\hline & & DMT & $\mathrm{Y}=96.2162-0.1827^{* *} \mathrm{~N}+0.0005996^{\circ} \mathrm{N}^{2}$ & 0.80 \\
\hline & & $\mathrm{OM}$ & $\mathrm{Y}=847.650+0.4405 * * \mathrm{~N}+0.2486 * \mathrm{P}+0.001164 * \mathrm{P}^{2}-0.004057 * \mathrm{NP}$ & 0.74 \\
\hline \multirow[t]{3}{*}{ Tertiary } & Biannual & $\mathrm{CP}$ & $\mathrm{Y}=91.4421+0.1083 * * \mathrm{~N}-0.4467 * * \mathrm{P}+0.002303 * * * \mathrm{P}^{2}$ & 0.69 \\
\hline & & TC & $\mathrm{Y}=717.5290+0.6244 * * \mathrm{~N}+0.7238^{* * * \mathrm{P}-0.006779 * * * \mathrm{NP}}$ & 0.62 \\
\hline & & $\mathrm{NDF}$ & $\mathrm{Y}=422.4950-1.800 * * * \mathrm{~N}+1.6244 * * * \mathrm{P}-0.01028 * * * \mathrm{P}^{2}+0.008277 * \mathrm{NP}$ & 0.95 \\
\hline
\end{tabular}

(1)Lack of fit to doses of $\mathrm{N}$ and P. ***,***and ${ }^{\circ}$ Significant at $0.1,1,5$, and $10 \%$ probability, respectively. 
harvesting in Tejuçuoca, and for tertiary cladodes in annual and biannual harvesting in Tejuçuoca, with the highest CP content with the dose of $190 \mathrm{~kg} \mathrm{ha}^{-1} \mathrm{~N}$ per year. The increase in $\mathrm{N}$ doses increases the availability and, consequently, the uptake of this nutrient by the roots at levels that probably exceeded the capacity of the plant to metabolize $\mathrm{N}$, which resulted in greater accumulation of $\mathrm{N}$ in the shoot (Taiz \& Zeiger, 2006). This would explain the direct relationship between $\mathrm{N}$ concentration in the soil and CP content of cactus pear, as observed by Dubeux Jr. et al. (2006) and Donato et al. (2014).

However, $\mathrm{N}$ doses affected negatively the $\mathrm{CP}$ content of primary cladodes under biannual harvesting in Quixadá and Tejuçuoca and of secondary cladodes under biannual harvesting, in Tejuçuoca. Old cladodes do not accumulate $\mathrm{CP}$ because most of the absorbed nutrient is mobilized to young cladodes (Nerd \& Nobel, 1995). Longer harvest time and $\mathrm{N}$ fertilization (Cunha et al., 2012) may increase the number of cladodes per cactus pear and, consequently, sink force (PimientaBarrios et al., 2005).

The CP content of cladodes in Tejuçuoca at the two harvesting frequencies was close to the optimum of 60 to $80 \mathrm{~g} \mathrm{~kg}^{-1} \mathrm{DM}$ for the growth of ruminal microorganisms (Lazzarini et al., 2009). However, in Quixadá, CP levels in primary and secondary cladodes with biannual harvesting were below the optimum for microbial growth. In the latter case, the sandy soil, with lower $\mathrm{OM}$ content and lower moisture retention, may have contributed to reduce root-nutrient contact and reduced $\mathrm{N}$ availability in the soil solution. The low CP content in cladodes under biannual harvesting in Quixadá showed the need for protein supplementation of the herd (Gebremariam et al., 2006; Tegegne et al., 2007). In Tejuçuoca, better soil conditions, such as moisture and natural fertility, may have contributed to a higher uptake of $\mathrm{N}$ and $\mathrm{P}$. These nutrients present in the soil are absorbed concomitantly, via symport, because they have opposite charge ions, and phosphate fertilization also provides more energy in the form of adenosine triphosphate for ammonium assimilation (Prado, 2008).

The NDF content of primary cladodes at the two harvesting frequencies in both sites increased with fertilization, fitting to the polynomial model. In both Quixadá (Table 1) and Tejuçuoca (Table 2), the maximum NDF content was obtained for annual and biannual harvesting, with estimated levels of 636.1 and $622.4 \mathrm{~g} \mathrm{~kg}^{-1} \mathrm{DM}$ for Quixadá, and 622.2 and 698.4 $\mathrm{g} \mathrm{kg}^{-1} \mathrm{DM}$ for Tejuçuoca, respectively. The increase in fertilization doses also increased the NDF content of secondary cladodes under annual harvesting in Quixadá and under annual and biannual harvesting in Tejuçuoca and of tertiary cladodes under annual harvest in Tejuçuoca. However, the NDF content of secondary cladodes under annual harvest in Quixadá and of tertiary cladodes under biannual harvesting in Tejuçuoca was reduced with the doses of $\mathrm{N}$.

The effect of fertilization on the growth of the whole cactus pear plant may result in higher or lower NDF content of cladodes. In an experiment to stimulate cactus pear growth (Dubeux Jr. et al., 2006; Ramos et al., 2015), fertilization tended to increase the NDF content of cladodes closer to the base of the plant and to reduce that of cladodes closer to the apex, because they are more tender and younger (Pinos-Rodríguez et al., 2010). The NDF content of secondary cladodes in Quixadá and of tertiary cladodes in Tejuçuoca, both under annual harvesting, was close to the levels of 248.8 and $318.8 \mathrm{~g} \mathrm{~kg}^{-1} \mathrm{DM}$ found by Batista et al. (2009) and Silva et al. (2013), respectively. However, these values were much lower when compared with the NDF contents of the other orders in the different harvesting and site conditions. In this context, the cladode order can be used as a criterion, in an attempt to optimize the use of cactus pear in the ruminant diet. The use of basal cladodes can affect the sustainability and productivity of cactus pear plantations. Alves et al. (2007) observed, at the density of 5,000 plants per hectare, under biannual harvest, greater production of cactus pear biomass in the conservation of secondary cladodes than of primary cladodes; however, at the density of 10,000 plants per hectare, there was no effect of the cut intensity on forage production, showing, in this case, that secondary cladodes can be used without compromising the productivity of the crop.

The OM content of the cladodes evaluated increased with the doses of $\mathrm{N}$ and/or $\mathrm{P}$, fitting to the polynomial model, except for primary and secondary cladodes under annual harvesting in Tejuçuoca, where there was a quadratic effect of the $\mathrm{N}$ and $\mathrm{P}$ doses, respectively. In Quixadá, the maximum OM content of primary cladodes under biannual harvesting and of secondary cladodes under annual and biannual harvesting presented estimated content values of 934.9, 935.7, and $927.0 \mathrm{~g} \mathrm{~kg}^{-1} \mathrm{DM}$, respectively. In Tejuçuoca, 
the maximum estimated OM contents of primary, secondary, and tertiary cladodes under annual and biannual harvesting were 898.0 and $917.0 \mathrm{~g} \mathrm{~kg}^{-1} \mathrm{DM}$, 901.4 and $908.8 \mathrm{~g} \mathrm{~kg}^{-1} \mathrm{DM}$, and 931.8 and $926.2 \mathrm{~g} \mathrm{~kg}^{-1}$ $\mathrm{DM}$, respectively.

The increase in the OM content of cladodes with fertilization is a consequence of the indirect effect of the nutrients available in the soil on the cactus pear plant growth, resulting in a higher NDF content. The reduction in $\mathrm{OM}$ content as a function of fertilization may be associated with a dilution effect caused by the greater number of young cladodes that are richer in minerals and poorer in NDF. OM content similar to that of the present study was verified by Tosto et al. (2007), Costa et al. (2010), Pereira et al. (2010), and Silva et al. (2013), who obtained values of 907.1, 832.9, 868.7 , and $837.0 \mathrm{~g} \mathrm{~kg}^{-1} \mathrm{DM}$, respectively.

The TC content of primary cladodes under annual harvestingin Quixadá(Table 1)increased quadractically as a function of $\mathrm{N}$ doses, with a maximum content of $836.6 \mathrm{~g} \mathrm{~kg}^{-1} \mathrm{DM}$ obtained at the dose $92.4 \mathrm{~kg} \mathrm{ha}^{-1} \mathrm{~N}$ per year. In contrast, the TC contents of secondary and tertiary cladodes, both under annual harvesting, in Tejuçuoca (Table 2), linearly reduced with the doses of $\mathrm{P}$ and $\mathrm{N}$, with maximum contents of 794.8 and 753.3 $\mathrm{g} \mathrm{kg}^{-1} \mathrm{DM}$, respectively, with the doses of 10 and 10 kg ha-1 per year $\mathrm{P}_{2} \mathrm{O}_{5}$ and $\mathrm{N}$. In the other management situations, there was a fit to the polynomial model. The highest TC content was related to the increase in NDF content with fertilization, probably due to a greater stimulus to cactus pear plant growth. When evaluating the whole plant, Silva et al. (2013) did not observe the same effect, because the TC content reduced with fertilization, due to the increase of new cladodes that are poor in structural carbohydrates, showing dilution effect. The increase in protein content according to $\mathrm{N}$ fertilization may also reduce TC content, because a fraction of soluble carbohydrates is used as a carbon skeleton source for protein synthesis (Peyraud \& Astigarraga, 1998).

The biannual harvesting resulted in higher DMT content of primary and secondary cladodes in Quixadá (Table 3), probably due to the higher maturity stage of the plant. This also justifies the higher contents of

Table 3. Contents of total dry matter (DMT), organic matter (OM), crude protein (CP), total carbohydrates (TC), and neutral detergent fiber (NDF) of primary and secondary cladodes of 'Gigante' cactus pear (Opuntia ficus-indica) according to the harvesting frequency (annual and biannual), in the municipality of Quixadá, in the state of Ceará, Brazil ${ }^{(1)}$.

\begin{tabular}{|c|c|c|c|c|c|c|c|c|}
\hline \multirow[t]{2}{*}{ Nutrient } & \multicolumn{2}{|c|}{ Primary } & \multirow[t]{2}{*}{ SEM } & \multirow[t]{2}{*}{ p-value } & \multicolumn{2}{|c|}{ Secondary } & \multirow[t]{2}{*}{ SEM } & \multirow[t]{2}{*}{ p-value } \\
\hline & Annual & Biannual & & & Annual & Biannual & & \\
\hline DMT $\left(\mathrm{g} \mathrm{kg}^{-1}\right)$ & $136.03 \mathrm{~b}$ & $186.11 \mathrm{a}$ & 0.78 & $<0.0001$ & $148.33 b$ & $180.62 \mathrm{a}$ & 0.85 & 0.0315 \\
\hline $\mathrm{OM}\left(\mathrm{g} \mathrm{kg}^{-1}\right)$ & $917.39 \mathrm{~b}$ & $927.59 \mathrm{a}$ & 0.20 & 0.0009 & $899.54 b$ & $919.48 \mathrm{a}$ & 0.31 & $<0.0001$ \\
\hline $\mathrm{CP}\left(\mathrm{g} \mathrm{kg}^{-1}\right)$ & $63.78 \mathrm{a}$ & $40.90 \mathrm{~b}$ & 0.31 & $<0.0001$ & $78.67 \mathrm{a}$ & $46.04 b$ & 0.41 & $<0.0001$ \\
\hline $\mathrm{TC}\left(\mathrm{g} \mathrm{kg}^{-1}\right)$ & $828.86 b$ & $868.00 \mathrm{a}$ & 0.55 & $<0.0001$ & $798.22 \mathrm{~b}$ & $847.60 \mathrm{a}$ & 0.64 & $<0.0001$ \\
\hline $\operatorname{NDF}\left(\mathrm{g} \mathrm{kg}^{-1}\right)$ & $294.36 b$ & $347.77 \mathrm{a}$ & 1.27 & 0.0003 & $258.75 b$ & $291.14 \mathrm{a}$ & 0.63 & 0.0022 \\
\hline
\end{tabular}

${ }^{(1)}$ Means followed by equal letters, in the rows, do not differ significantly by Tukey's test, at $5 \%$ probability. SEM, standard error of the mean.

Table 4. Contents of total dry matter (DMT), organic matter (OM), crude protein (CP), total carbohydrates (TC), and neutral detergent fiber (NDF) of primary, secondary, and tertiary cladodes of 'Gigante' cactus pear (Opuntia ficus-indica) according to the harvesting frequency (annual and biannual), in the municipality of Tejuçuoca, state of Ceará, Brazil ${ }^{(1)}$.

\begin{tabular}{|c|c|c|c|c|c|c|c|c|c|c|c|c|}
\hline \multirow[t]{2}{*}{ Nutrient } & \multicolumn{2}{|c|}{ Primary } & \multirow[t]{2}{*}{ SEM } & \multirow[t]{2}{*}{ p-value } & \multicolumn{2}{|c|}{ Secondary } & \multirow[t]{2}{*}{ SEM } & \multirow[t]{2}{*}{ p-value } & \multicolumn{2}{|c|}{ Tertiary } & \multirow[t]{2}{*}{ SEM } & \multirow[t]{2}{*}{$\mathrm{p}$-value } \\
\hline & Annual & Biannual & & & Annual & Biannual & & & Annual & Biannual & & \\
\hline DMT $\left(\mathrm{g} \mathrm{kg}^{-1}\right)$ & $105.61 \mathrm{a}$ & $107.52 \mathrm{a}$ & 0.16 & 0.3611 & $94.08 \mathrm{a}$ & $95.66 \mathrm{a}$ & 0.13 & 0.5314 & $84.75 a$ & $85.39 \mathrm{a}$ & 0.09 & 0.7612 \\
\hline $\mathrm{OM}\left(\mathrm{g} \mathrm{kg}^{-1}\right)$ & $895.68 b$ & $904.77 \mathrm{a}$ & 0.26 & 0.0077 & $890.62 b$ & $898.42 \mathrm{a}$ & 0.23 & 0.0302 & $874.30 \mathrm{~b}$ & $885.55 \mathrm{a}$ & 0.24 & 0.0083 \\
\hline $\mathrm{CP}\left(\mathrm{g} \mathrm{kg}^{-1}\right)$ & $73.68 \mathrm{a}$ & $68.78 \mathrm{a}$ & 0.22 & 0.0919 & $85.96 \mathrm{a}$ & $72.08 \mathrm{~b}$ & 0.26 & $<0.0001$ & $115.22 \mathrm{a}$ & $86.16 b$ & 0.46 & $<0.0001$ \\
\hline $\mathrm{TC}\left(\mathrm{g} \mathrm{kg}^{-1}\right)$ & $805.28 b$ & $825.01 \mathrm{a}$ & 0.37 & 0.0002 & $780.33 b$ & $806.26 \mathrm{a}$ & 0.45 & 0.0003 & $735.69 b$ & $776.44 a$ & 0.60 & $<0.0001$ \\
\hline $\operatorname{NDF}\left(\mathrm{g} \mathrm{kg}^{-1}\right)$ & $377.43 b$ & $469.07 \mathrm{a}$ & 1.46 & $<0.0001$ & $291.04 b$ & $424.24 \mathrm{a}$ & 1.95 & $<0.0001$ & $262.59 \mathrm{~b}$ & $370.13 a$ & 1.57 & $<0.0001$ \\
\hline
\end{tabular}

${ }^{(1)}$ Means followed by equal letters, in the rows, do not differ significantly by Tukey's test, at 5\% probability. SEM, standard error of the mean. 
OM, TC, and NDF in primary and secondary cladodes under biannual harvesting in Quixadá. In Tejuçuoca (Table 4), although higher contents of OM, TC, and NDF of primary, secondary, and tertiary cladodes were verified in biannual harvesting, the DMT content of these cladodes did not vary with the frequency of harvesting; moreover, in this case, the sandy loam soil with higher rainwater storage capacity in Tejuçuoca resulted in more hydrated cladodes.

The CP content of cladodes was lower under biannual than annual harvesting, at both sites, except for primary cladodes in Tejuçuoca, where there was similarity between harvesting frequencies. The maturity process results in a reduction in $\mathrm{CP}$ content and in an increase in the NDF content of cactus pear (Pinos-Rodríguez et al., 2010).

\section{Conclusions}

1. The effect of combined nitrogen and phosphorus fertilization on the contents of total dry matter, crude protein, neutral detergent fiber, organic matter, and total carbohydrate of 'Gigante' cactus pear (Opuntia ficusindica) cladodes varies with the annual or biannual harvesting frequency, and with the municipality, i.e., Quixadá or Tejuçuoca in the state of Ceará, Brazil.

2 . The annual harvesting of cactus pear improves the nutritional quality of primary and secondary cladodes in Quixadá, and of secondary and tertiary cladodes, in Tejuçuoca.

3. The biannual harvest, in both municipalities, promotes higher content of organic matter, total carbohydrates and neutral detergent fiber, and lower crude protein content in cladodes.

\section{Acknowledgments}

To Banco do Nordeste do Brasil (BNB), for financial support.

\section{References}

ALVES, R.N.; FARIAS, I.; MENEZES, R.S.C.; LIRA, M. de A.; SANTOS, D.C. dos. Produção de forragem pela palma após 19 anos sob diferentes intensidades de corte e espaçamentos. Revista Caatinga, v.20, p.38-44, 2007.

BATISTA, Â.M.V.; RIBEIRONETO, A.C.; LUCENA, R.B.; SANTOS, D.C.; DUBEUX JR., J.B.; MUSTAFA, A.F. Chemical composition and ruminal degradability of spineless cactus grown in Northeastern Brazil. Rangeland Ecology \& Management, v.62, p.297-301, 2009. DOI: 10.2111/07-099R1.1.

COSTA, M.R.G.F.; CARNEIRO, M.S. de S.; PEREIRA, E.S.; FEITOSA, J.V.; SALES, R. de O.; MORAIS NETO, L.B. de; PEIXOTO, M.J.A. Produção e composição química da palma forrageira micropropagada in vitro. Revista Brasileira de Saúde e Produção Animal, v.11, p.953-960, 2010.

CUNHA, D. de N.F.V. da; GOMES, E. dos S.; MARTUSCELLO, J.A.; AMORIM, P.L. de; SILVA, R.C.; FERREIRA, P.S. Morfometria e acúmulo de biomassa em palma forrageira sob doses de nitrogênio. Revista Brasileira de Saúde e Produção Animal, v.13, p.1156-1165, 2012. DOI: 10.1590/S151999402012000400005 .

DONATO, P.E.R.; PIRES, A.J.V.; DONATO, S.L.R.; SILVA, J.A. da; AQUINO, A.A. de. Valor nutritivo da palma forrageira 'gigante' cultivada sob diferentes espaçamentos e doses de esterco bovino. Revista Caatinga, v.27, p.163-172, 2014.

DUBEUX JR., J.C.B.; SANTOS, M.V.F.; LIRA, M.A.; SANTOS, D.C.; FARIAS, I.; LIMA, L.E.; FERREIRA, R.L.C. Productivity of Opuntia ficus-indica (L.) Miller under different $\mathrm{N}$ and $\mathrm{P}$ fertilization and plant population in northeast Brazil. Journal of Arid Environments, v.67, p.357-372, 2006. DOI: 10.1016/j. jaridenv.2006.02.015.

DUBEUX JÚNIOR, J.C.B.; ARAÚJO FILHO, J.T. de; SANTOS, M.V.F. dos; LIRA, M. de A.; SANTOS, D.C. dos; PESSOA, R.A.S. Adubação mineral no crescimento e composição mineral da palma forrageira - Clone IPA-201. Revista Brasileira de Ciências Agrárias, v.5, p.129-135, 2010.

GEBREMARIAM, T.; MELAKU, S.; YAMI, A. Effect of different levels of cactus (Opuntia ficus-indica) inclusion on feed intake, digestibility and body weight gain in tef (Eragrostis tef) strawbased feeding of sheep. Animal Feed Science and Technology, v.131, p.43-52, 2006. DOI: 10.1016/j.anifeedsci.2006.02.003.

HELRICH, K. (Ed.). Official methods of analysis of the AOAC. $15^{\text {th }}$ ed. Arlington: Association of Official Analytical Chemists, 1990. 1117 p.

LAZZARINI, I.; DETMANN, E.; SAMPAIO, C.B.; PAULINO, M.F.; VALADARES FILHO, S.C.; SOUZA, M.A.; OLIVEIRA, F.A. Dinâmicas de trânsito e degradação da fibra em detergente neutro em bovinos alimentados com forragem tropical de baixa qualidade e compostos nitrogenados. Arquivo Brasileiro de Medicina Veterinária e Zootecnia, v.61, p.635-647, 2009. DOI: 10.1590/S0102-09352009000300017.

NERD, A.; MIZRAHI, Y. Effect of nitrogen fertilization and organ removal on rebudding in Opuntia fícus-indica (L.) Miller. Scientia Horticulturae, v.59, p.115-122, 1994. DOI: 10.1016/03044238(94)90078-7.

NERD, A.; NOBEL, P.S. Accumulation, partitioning, and assimilation of nitrate in Opuntia ficus-indica. Journal of Plant Nutrition, v.18, p.2533-2549, 1995. DOI: 10.1080/01904169509365083.

NOBEL, P.S.; ZUTTA, B.R. Temperature tolerances for stems and roots of two cultivated cacti, Nopalea cochenillifera and Opuntia robusta: acclimation, light and drought. Journal of 
Arid Environments, v.72, p.633-642, 2008. DOI: 10.1016/j. jaridenv.2007.08.005.

PEREIRA, E.S.; PIMENTEL, P.M.; DUARTE, L.S.; MIZUBUTI, I.Y.; ARAÚJO, G.G.L. de; CARNEIRO, M.S. de S.; REGADAS FILHO, J.G.L.; MAIA, I.S.G. Determinação das frações protéicas e de carboidratos e estimativa do valor energético de forrageiras e subprodutos da agroindústria produzidos no nordeste brasileiro. Semina: Ciências Agrárias, v.31, p.1079-1094, 2010. DOI: 10.5433/1679-0359.2010v31n4p1079.

PEYRAUD, J.L.; ASTIGARRAGA, L. Review of the effect of nitrogen fertilization on the chemical composition, intake, digestion and nutritive value of fresh herbage: consequences on animal nutrition and $\mathrm{N}$ balance. Animal Feed Science and Technology, v.72, p.235-259, 1998. DOI: 10.1016/S03778401(97)00191-0.

PIMIENTA-BARRIOS, E.; ZAÑUDO-HERNANDEZ， J.; ROSAS-ESPINOZA, V.C.; VALENZUELA-TAPIA, A.; NOBEL, P.S. Young daughter cladodes affect $\mathrm{CO}_{2}$ uptake by mother cladodes of Opuntia ficus-indica. Annals of Botany, v.95, p.363369, 2005. DOI: 10.1093/aob/mci034.

PINOS-RODRÍGUEZ, J.M.; VELÁZQUEZ, J.C.; GONZÁLEZ, S.S.; AGUIRRE, J.R.; GARCÍA, J.C.; ÁLVAREZ, G.; JASSO, Y. Effects of cladode age on biomass yield and nutritional value of intensively produced spineless cactus for ruminants. South African Journal of Animal Science, v.40, p.245-250, 2010. DOI: 10.4314/sajas.v40i3.14.

PRADO, R. de M. Manual de nutrição de plantas forrageiras. Jaboticabal: Funep, 2008. 500p.

RAMOS, J.P. de F.; SANTOS, E.M.; CRUZ, G.R.B.; PINHO, R.M.A.; FREITAS, P.M.D. de. Effects of harvest management and manure levels on cactus pear productivity. Revista Caatinga, v.28, p.135-142, 2015.

RIBEIRO, E.M. de O.; SILVA, N.H. da; LIMA FILHO, J.L. de; BRITO, J.Z. de; SILVA, M. da P.C. da. Study of carbohydrates present in the cladodes of Opuntia ficus-indica (fodder palm), according to age and season. Ciência e Tecnologia de Alimentos, v.30, p.933-939, 2010. DOI: 10.1590/S0101-20612010000400015.
SAEG: Sistema para Análises Estatísticas, versão 9.1. Viçosa: UFV, 2007.

SANTOS, D.C. dos; FARIAS, I.; LIRA, M. de A.; SANTOS, M.V.F. dos; ARRUDA, G.P. de; COELHO, R.S.B.; DIAS, F.M.; MELO, J.N. de. Manejo e utilização da palma forrageira (Opuntia e Nopalea) em Pernambuco. Recife: IPA, 2006. 48p. (IPA. Documentos, 30).

SILVA, J.A.; BONOMO, P.; DONATO S.L.R.; PIRES, A.J.V.; SILVA, F.F.; DONATO, P.E.R. Composição bromatológica de palma forrageira cultivada em diferentes espaçamentos e adubações química. Revista Brasileira de Ciências Agrárias, v.8, p.342-350, 2013. DOI: 10.5039/agraria.v8i2a2431.

SNIFFEN, C. J.; O'CONNOR, J.D.; VAN SOEST, P.J.; FOX, D.G.; RUSSELL, J.B. A net carbohydrate and protein system for evaluating cattle diets. II. Carbohydrate and protein availability. Journal of Animal Science, v.70, p.3562-3577, 1992. DOI: $10.2527 / 1992.70113562 x$.

TAIZ, L.; ZEIGER, E. Plant Physiology. $4^{\text {th }}$ ed. Sunderland: Sinauer, 2006.

TEGEGNE, F.; KIJORA, C.; PETERS, K.J. Study on the optimal level of cactus pear (Opuntia ficus-indica) supplementation to sheep and its contribution as source of water. Small Ruminant Research, v.72, p.157-164, 2007. DOI: 10.1016/j. smallrumres.2006.10.004.

TOSTO, M.S.L.; ARAÚJO, G.G.L.; OLIVEIRA, R.L.; BAGALDO, A.R.; DANTAS, F.R.; MENEZES, D.R.; CHAGAS, E.C.O. Composição química e estimativa de energia da palma forrageira e do resíduo desidratado de vitivinícolas. Revista Brasileira de Saúde e Produção Animal, v.8, p.239-249, 2007.

TURRENT FERNÁNDEZ, A.; LAIRD, R.J. La matriz experimental Plan Puebla, para ensayos sobre practicas de produccion de cultivos. Agrociencia, v.9, p.117-143, 1975.

VAN SOEST, P.J.; ROBERTSON, J.B. Analysis of forages and fibrous foods. Ithaca: Cornell University, 1985. 202p.

Received on February 6, 2017 and accepted on May 8, 2017

Pesq. agropec. bras., Brasília, v.53, n.2, p.221-228, Feb. 2018

DOI: 10.1590/S0100-204X2018000200011 